DOI: 10.19195/0137-1150.163.63

\author{
MAGDALENA ŚLAWSKA \\ Uniwersytet Wrocławski, Polska \\ magdalena.slawska@uwr.edu.pl
}

\title{
Doświadczenie starości w prozie autobiograficznej Bory Ćosicia
}

\author{
Stary człowiek nie straszy nikogo własna \\ śmiercia, \\ nie dzieli się z nikim swoja rozpacza $i$ nie \\ skarży się, \\ że wszystko było dla niego najpierw za \\ wcześnie, a potem za późno.
}

Julia Hartwig $^{1}$

W świadomości społecznej wiele jest stereotypów odnoszących się do ludzi starych. Chociaż nieobce są obrazy starości dostojnej, otoczonej czcią i szacunkiem, najczęściej widzimy ją jako smutną i niedołężną, a ludzie w podeszłym wieku ukazywani są jako upadający na zdrowiu, niesprawni fizycznie czy uzależnieni finansowo od innych ${ }^{2}$. Wyobrażenia te szczególnie żywe są wśród ludzi młodych ${ }^{3}$. Odpowiedzialną za taki stan rzeczy uznać należy kulturę terroru młodości, której poddajemy się bardziej lub mniej świadomie, stosując różnorodne metody zatrzymania rzeki życia. W dobie płynnej nowoczesności doświadczenie czasu i jego percepcja zdominowane zostały przez poczucie kruchości. Przemijas. 9.

${ }^{1}$ J. Hartwig, *** (Stary człowiek upadt w błoto), [w:] eadem, Chwila postoju, Kraków 1980,

${ }^{2}$ Wyobrażenia na temat ludzi starych wymienia i szczegółowo charakteryzuje Adam Zych. Zob. A. Zych, Stereotypowe wyobrażenia oraz mity na temat starości i ludzi w podeszłym wieku, [w:] idem, Człowiek wobec starości. Szkice z gerontologii społecznej, Warszawa 1995, s. 139-142. Zob. także G. Nowak-Starz et.al., Spoteczny obraz starości XXI wieku, [w:] Starość - obawy, nadzieje, oczekiwania. Wybrane zagadnienia z gerontologii, red. B. Zboiny, G. Nowak-Starz, Ostrowiec Świętokrzyski 2009, s. 17-38.

${ }^{3}$ Szeroko na ten temat pisze Ewa Wysocka. Zob. E. Wysocka, Człowiek „stary” w spoteczeństwie ponowoczesnym - stereotyp starości i procesu starzenia się w świadomości młodzieży, [w:] Starość raz jeszcze..., red. J. Olejniczak, S. Zając, Katowice 2007, s. 53-74. 
niu podlega nie tylko ludzkie życie, ale i wszelkie wytwory kultury materialnej. „Każda rzecz pojawia się na świecie naznaczona piętnem niechybnej śmierci; każda rzecz schodzi z taśmy produkcyjnej z wyznaczonym jej »terminem ważności «"4 - konstatuje Zygmunt Bauman.

Na przekór negatywnym wyobrażeniom na temat ludzi w podeszłym wieku pojawiło się w ostatnim czasie wiele prac, które oddemonizowują obraz starości. Specjaliści z różnych dziedzin — gerontolodzy, fizjolodzy, socjologowie, pedagogowie oraz psycholodzy starający się uchwycić złożoność procesu starzenia — w swoich dociekaniach koncentrują się obecnie przede wszystkim na pozytywnych stronach ostatniego etapu życia ${ }^{5}$. Podkreślić trzeba, iż określenie ,pozytywna starość" (positive aging), zastępowane często mianem „pomyślna starość" (successful aging), podniesione zostało do rangi terminu naukowego. Pojęcia te ściśle wiążą się z założeniami psychologii pozytywnej, w której polu zainteresowania leżą:

na poziomie podmiotu [...] cenne doświadczenia subiektywne: dobrostan, zadowolenie i satysfakcja (w przeszłości), nadzieja i optymizm (na przyszłość) oraz [...] szczęście (w teraźniejszości). Na poziomie indywidualnym skupia się ona na pozytywnych cechach indywidualnych: zdolności kochania i współczucia, odwadze, zdolnościach interpersonalnych, wrażliwości estetycznej, wytrwałości, wielkoduszności, oryginalności, myśleniu o przyszłości, duchowości, talencie i mądrości 6 .

Obraz starości i starzenia się w ujęciu zwolenników psychologii pozytywnej stanowi przeciwwagę dla modelu chorobowego. Badacze zamiast skupiać się na ludzkich słabościach i błędach, akcentują siłę, witalność, dobro, zdolności i umiejętności. Robert Hill zaznacza, iż: „termin pozytywne starzenie się opisuje człowieka wykorzystującego dostępne mu zasoby w celu zoptymalizowania doświadczenia starzenia się"7. Z kolei George Vaillant dodaje:

pozytywne starzenie się musi zawsze odzwierciedlać istotną reakcję na zmiany, na chorobę oraz na nierównowagę otoczenia; pozytywne starzenie się nie polega na unikaniu strat na zdrowiu i na pewno nie polega na unikaniu śmierci ${ }^{8}$.

Badacze podkreślają, iż ludzie starzejący się w sposób pozytywny zdają sobie sprawę z realiów starości oraz nieuchronności śmierci. Nie tylko są pogodzeni z tą sytuacją, lecz także — jak podkreśla Anna Gronostaj — „dostosowują swój

${ }^{4}$ Z. Bauman, Życie na przemiat, Kraków 2004, s. 152.

5 Taki obraz starości ukazują między innymi prace o wymownych tytułach: Starość - wiek spetnienia, Starość czasem nadziei czy Kako do uspešne starosti. Zob. Starość - wiek spetnienia, red. W. Dzieduszycki, J. Wrzesiński, Poznań 2006; A. Pronzato, Starość czasem nadziei, przeł. A. Ryndak-Laciuga, Kraków 2000; S. Jovanović, Kako do uspešne starosti, Beograd 2002.

${ }^{6}$ M.E.P. Seligman, M. Csikszentmihalyi, Positive psychology: An Introduction. „American Psychologist" 2000, nr 55, s. 1, cyt. za: R.D. Hill, Pozytywne starzenie się. Młodzi duchem w jesieni życia, przeł. M. Lipa, Warszawa 2009, s. 14.

${ }^{7}$ R.D. Hill, Pozytywne starzenie się..., s. 42.

${ }^{8}$ G.E. Vaillant, Aging Well. Surprising guideposts to a happier life, Boston 2002, s. 161, cyt. za: R.D. Hill, Pozytywne starzenie się..., s. 43. 
styl życia do zmieniającej się formy fizycznej, szukając nowych i zadowalających doświadczeń" ". Są aktywni towarzysko (utrzymują kontakt z rodziną, znajomymi i nawiązują nowe przyjaźnie), nadal pozostają czynni zawodowo (pracują w mniejszym wymiarze godzin lub w ramach wolontariatu) oraz podejmują wyzwania intelektualne.

Reasumując, podkreślić trzeba, iż starość coraz częściej postrzegana jest jako wartościowe doświadczenie człowieka, jako kolejny etap życia i rozwoju, a nie ostatnia prosta prowadząca do mety, którą jest śmierć. Potwierdzeniem tego jest spore $\mathrm{w}$ ostatnich latach zainteresowanie problematyką starzenia się, dostrzegane również w zakresie literatury oraz badań literaturoznawczych. Philippe Ariès blisko trzydzieści lat temu zauważył, że „Teraz będzie wiele prac na temat starych ludzi: już je rozpoczęto. I sądzę, że jeśli ktoś wkroczy na ten ugór, pójdzie za nim uniwersytecki kombajn i wkrótce powstanie cała biblioteka dzieło o starości"10. Prognozy francuskiego filozofa okazały się trafne. Dysponujemy dziś pokaźną biblioteką prac poświęconych obrazom starości i starzenia się. W Polsce zagadnienie to stało się na przestrzeni ostatnich dziesięciu lat motywem przewodnim kilku konferencji naukowych i monografii zbiorowych ${ }^{11}$. Również badacze południowosłowiańscy dostrzegli w starości ważny temat kultury ${ }^{12}$. Próbując wpisać się w nakreślony nurt badań, w niniejszym szkicu pragnę skierować uwagę na wizję starzenia się oraz postawę wobec tego zjawiska obecne w prozie autobiograficznej Bory Ćosicia. Cel, który będzie mi przyświecał, to rekonstrukcja procesu

${ }^{9}$ A. Gronostaj, „Pozytywna starość” w opowiadaniu Ernesta Hemingwaya ,, Stary człowiek i morze”, [w:] Wielkie tematy literatury amerykańskiej VI. Starość. Śmierć, red. T. Pyzik, A. Woźniakowska, Katowice 2014, s. 11.

${ }^{10}$ Cyt. za: G. Minois Historia starości. Od antyku do renesansu, przeł. K. Marczewska, Warszawa 1995, s. 15.

${ }^{11}$ Wspomnieć trzeba o przywoływanych już pracach: Starość raz jeszcze... oraz Wielkie tematy literatury amerykańskiej VI. Starość. Śmierć... Zob. także: Starość. Wybór materiałów z VII Konferencji Pracowników Naukowych i Studentów Instytutu Nauk o Literaturze Polskiej UŚ, red. A. Nawarecki, A. Dziadek, Katowice 1995; Dojrzewanie do petni życia. Starość w literaturze polskiej i obcej, red. S. Kruk, E. Flis-Czerniak, Lublin 2006; Egzystencjalne doświadczenie starości w literaturze, red. A. Gleń, I. Jokiel, M. Szladowski, Opole 2008; Starość. Doświadczenie egzystencjalne, temat literacki, metafora kultury, seria I. Rozpoznania, red. A. Janicka, E. Wesołowska, G. Kowalski, Białystok 2013; Starość. Doświadczenie egzystencjalne, temat literacki, metafora kultury, seria II. Zapisy i odczytania, red. A. Janicka, E. Wesołowska, Ł. Zabielski, Białystok 2013.

12 Wymienić należy m.in. prace autorstwa Radovana Mirkovicia, Marka Nedicia, Snežany Samardžiji czy Srđana Papicia. Zob. R. Mirković, Starost $i$ smrt u autobiografskim zapisima Ive Andrića, [w:] Srpska autobiografska književnost. Naučni sastanak slavista u Vukove dane, ured. B. Ćorić, Beograd 1998, s. 291-298; M. Nedić, Sve je prolazno samo je prolaznost trajna. Varijacije na temu trajno i efemerno u filozofiji i književnosti, „Bagdala. Mesečni list za književnost, umetnost i kulturu” 2014, god. 56, br. 501, s. 29-42; S. Samardžija, „Hej starosti, prteno oružje!”. Tipske odlike za staraca u žanrovima usmene proze, „Zbornik Matice srpske za književnost i jezik” 2011, knj. 59, sv. 3, s. 535-554; S. Papić, O starosti i mladosti, „Povelja. Časopis za književnost, umetnost, kulturu, prosvetna i društvena pitanja" 2008, br. 38, s. 28-33. 
dorastania czy dojrzewania do pozytywnej/pomyślnej starości, której dokonam w oparciu o wybrane utwory autora opublikowane po roku 1995.

Przyjęta przez mnie cezura wiąże się ściśle z ważnymi decyzjami życiowymi pisarza, które bezpośrednio przełożyły się na jego dorobek. W 1995 roku Ćosić jako stypendysta DAAD ${ }^{13}$ wyjechał do Berlina, w którym mieszka do dziśs ${ }^{14}$. Miał wówczas 63 lata. Wyjazd z ojczyzny wyznaczył początek nowego etapu życia oraz twórczości. W tekstach, które ukazały się na przestrzeni kolejnych dziesięciu lat - Novi stanar (1998), Starost u Berlinu (1998), Deklaracja celna (Carinska deklaracija, 2000), Podróż na Alaskę (Put na Aljasku, 2006), Konsul w Belgradzie (Consul u Beogradu, 2008), aż po zbiór zapisków zatytułowany Mirni dani u Rovinju (2014) — autor nie tylko dokonuje rekonstrukcji własnych losów, lecz także próbuje stawić czoła starości.

Swoje rozważania pragnę rozpocząć od Deklaracji celnej ${ }^{15}$. Książka ta ukazała się pięć lat po wyjeździe pisarza z kraju, jednak odnosi się on w niej do wydarzeń pod względem chronologicznym najwcześniejszych. Autor-narrator $\mathrm{w}$ momencie przekraczania granicy próbuje uzupełnić tytułową deklarację i rozliczyć się z dotychczasowego życia. W efekcie tekst zyskuje znamiona autobiografii. Próba rozrachunku z przeszłością nie przynosi jednak upragnionej ulgi, nie zaprowadza ładu. Niejasna tożsamość Ćosicia, którą próbuje na nowo skonstruować, koresponduje z problematyczną tożsamością Berlina, „miasta w tranzycji" ${ }^{\prime \prime}$, miasta o pogmatwanych dziejach — wschodniego i zachodniego jednocześnie ${ }^{17}$. Miejsce to początkowo jawi się Ćosiciowi jako nieprzyjazne i jest definiowane poprzez negację takich pojęć, jak dom czy kraj ojczysty. Intensyfikuje ono w pisarzu również poczucie wyobcowania ${ }^{18}$. Autor swoją ojczyznę definiuje jako „kraj na południu”, „,na jugu”, Berlin natomiast to miasto na północy i — jak czytamy — „sever našeg sveta"19. Opozycja północ-południe jest

${ }^{13}$ Laureatami stypendium przyznawanego przez Niemiecką Centralę Wymiany Akademickiej byli również inni pisarze pochodzący z krajów byłej Jugosławii. W domu pracy twórczej w Wannsee gościli m.in.: Daša Drndić, Dževad Karahasan, Dragan Velikić oraz David Albahari.

${ }^{14}$ W 1991 r. Ćosić opuścił Belgrad, w którym mieszkał od 1937 r., i przeprowadził się do Rovinja, gdzie posiada dom, w którym co roku spędza lato.

${ }^{15}$ Książka Carinska deklaracija ukazała się w Polsce w tłumaczeniu Danuty Cirlić-Straszyńskiej. Zob. B. Ćosić, Deklaracja celna, przeł. D. Cirlić-Straszyńska, Wołowiec 2003.

${ }^{16}$ Określenie to stosuję za Anitą Gostomską. Zob. A. Gostomska, Zagrzeb - Berlin - Amsterdam. O metaforze miasta w twórczości Dubravki Ugrešić, [w:] Miasto w kulturze chorwackiej, red. M. Falski, M. Kryska-Mosur, Warszawa 2008, s. 194.

17 Szerzej na temat obrazu Berlina obecnego w utworach autobiograficznych pisarzy postjugosłowiańskich piszę w opublikowanym w języku niemieckim artykule pt. Berlin w postjugosłowiańskiej prozie autobiograficznej. Zob. M. Ślawska, Die Stadt Berlin in der postjugoslawischen autobiografischen Prosa, [w:] Südslawen und die deutschsprachige Kultur, red. A. Buras-Marciniak, M. Gołaszewski, Frankfurt am Main 2015, s. 61-73.

${ }^{18}$ Problem ten omówiłam szerzej w szkicu pt. Modele obcości/inności w prozie autobiograficznej Bory Ćosicia. Zob. M. Ślawska, Modele obcości/inności w prozie autobiograficznej Bory Ćosicia, „Studia Slavica” 2015, nr XIX/2, s. 239-248.

19 B. Ćosić, Carinska deklaracija, Split 2000, s. 16. 
przez pisarza nieustannie podkreślana, na jej podstawie dokonuje się rozróżnienie między przeszłością a teraźniejszością. W ujęciu Ćosicia północ jest synonimem starości czy wręcz śmierci:

Starost je [...] nekakva klima, promenljiva, koja ovde na severu vrlo dobro uspeva. Kao da ceo svet najpre živi negde oko polutara, a tek kada počne da stari, uputi se ka severu, gde se nalazi prirodan kraj svakog života ${ }^{20}$.

Berlin zaś to cmentarzysko słoni (,groblje slonovsko”"21), gdzie twórca przybywa, by dokonać życia („da bi tu svoj život dokrajčio"22). Stwierdza, że tam znajduje się ,,adresa moje starosti” 23 oraz podkreśla, że:

Mi sada imamo jedan nov kup predmeta [...]. A oni koje smo znali, iščezli su u međuvremenu u našem zaboravu. Jer mi smo i sebe same zaboravili u obliku koji smo nekad imali, dobivši novu obrazinu sačinjenu od novih iskustava, drugojačije klime i starosti24.

Perypetie z nową, obcą przestrzenią Ćosić ukazuje nie tylko na kartach Deklaracji celnej, lecz także w utworach Novi stanar oraz Starost u Berlinu. We wszystkich wymienionych tekstach odnajdujemy podobny obraz niemieckiej stolicy. W chwili przyjazdu autor postrzegał ją przede wszystkim jako miejsce, w którym ze wszech stron otacza go starość. To miasto jest - można stwierdzić — „na emeryturze" 25 :

u njemu vidim veliku stanku koja nastupa, menopauzu Evrope, stare i umorne u svojoj funkciji plođenja. U hodniku se dogodilo skoro sve što se moglo dogoditi, čak i u kontinentalnim razmerama ${ }^{26}$.

Kondycja miasta intensyfikuje w pisarzu świadomość własnej starości, która postrzegana jest przez niego jako zjawisko negatywne:

[...] čovek u tako visokoj starosti može biti jedino izdajnik sopstvene mladosti. Koju je napustio odavno, pa se zaputio u dobu određenu za slonove. Tako i ja hodam u svojoj starosti, koja još uvek nije slonovska, ali ipak. Pa vidim malo slabije no pre, a tako stoji i sa mojim sluhom ${ }^{27}$.

Rozważania Ćosicia, zdominowane przez przemyślenia nad przemijaniem, kruchością ludzkiego życia, jego celem i sensem, prowadzą do bardzo pesymistycznych wniosków:

${ }^{20}$ Ibidem, s. 5.

${ }^{21}$ Ibidem, s. 9.

${ }^{22}$ Ibidem, s. 39.

${ }^{23}$ Zob. ibidem, s. 80.

24 Ibidem, s. 5.

${ }^{25}$ Określenie Elżbiety Tyszkowskiej-Kasprzak. Zob. E. Tyszkowska-Kasprzak, Stolica na emeryturze. Petersburg w prozie Olega Postnowa, [w:] Topografia tożsamości, t. 1, red. B. Zieliński, Poznań 2012, s. 19-27.

${ }^{26}$ B. Ćosić, Starost u Berlinu, Beograd 1998, s. 24. Metafora Europy jako kobiety w okresie menopauzy stanowi zdaniem Lidiji Vukčević próbę wyjaśnienia za pomocą mitów tego, co dla autora jest niezrozumiałe. Zob. L. Vukčević, Svijet kao osobni muzej u pisanju Bore Ćosića, „Književna republika" 2013, br. 1-3, s. 48.

27 B. Ćosić, Carinska..., s. 9. 
Sada, kada taj vek prolazi, kao i naš život, proveden u njemu, možemo samo da izmišljamo kako je onde, u tom vremenu trebalo živeti, a koko uglavnom živeli nismo. [...] Naš život u dvadesetom veku nema nekakav sadržaj. To je bila samo jedna gungula kao u najčuvenijim antiromanima, napisanim takođe u ovom vremenu ${ }^{28}$.

Starość kojarzy się mu przede wszystkim ze śmiercią. Pisząc o niej, używa epitetów o wyraźnym nacechowaniu pejoratywnym. W chwili, gdy opuszcza Belgrad, stwierdza: „Mislim kako ovom gradu sada uskraćujem svoju smrt. Koju sam bio namenio toj naseobini, a sada prema ovom mestu, geografskom, našeg kontinenta, nekakvu škrtost pokazujem" 29 . Z kolei uzasadniając decyzję o emigracji, podkreśla: ,[...] tamo dole raste nekakva nova država čije zakone je ne razumem a ni oni moju starost više ne dopuštaju" ${ }^{30}$. Ćosić, podobnie jak wielu innych pisarzy, stał się ofiarą procesu konfiskaty świeżej jeszcze jugosłowiańskiej pamięci zbiorowej, co doprowadziło do kryzysu tożsamości. „Ja još uopšte nisam ustanovio gde se šta nalazi u mojoj svesti, kao ni u sećanjima koja su vrlo zbrkana"31 _ stwierdza po przybyciu do Berlina. Pozbawienie go prawa do pamięci, wyzucie ze wspomnień - o domu, o młodości, o wszystkim, co bezpowrotnie utracił, co pozostało daleko na południu, postrzega jako jeden z symptomów starości. ,[...] ono što bile su moje godine oko dvadesete, to još uvek nikako na sever svetski, gde sam sad, ne uspevam da dovučem"32 — podkreśla. Przyjazd do nowego miejsca wyzwala w twórcy typowe dla ludzi starszych przekonanie, że nie jest nikomu potrzebny, że wszyscy go porzucili, nawet czas:

Ja danas živim u jednoj berlinskoj ulici, kao pojava takođe neupotrebljiva za mnogo šta što se oko mene dešava. [...] Ostavljen sve više od svoga vremena ${ }^{33}$. Ja sam jedno ostarelo dete dvadesetog veka ${ }^{34}$.

Swój pobyt w stolicy Niemiec określa mianem „lamant starenja u Berlinu”35 i niejednokrotnie podkreśla, że stracił kontrolę nad swoim życiem: „,...] moj život u Berlinu [...] je nečija predstava" 36 .

Ćosić stopniowo próbuje oswoić obcą przestrzeń; „počinje da raščišćava vlastiti autobiografski prostor, usled čega spisateljev život, iako već zamagljen, umnogome ostaje razaznatljiv" 37 — zauważa Predrag Brebanović. Odkrywa, że Berlin to przede wszystkim miasto twórców — pisarzy, filmowców, artystów. W jego rozważaniach pojawiają się, między innymi, nazwiska Waltera Benjamina, Marleny Ditrich, Franza Kafki, Vladimira Nabokova, Wima Wendersa czy

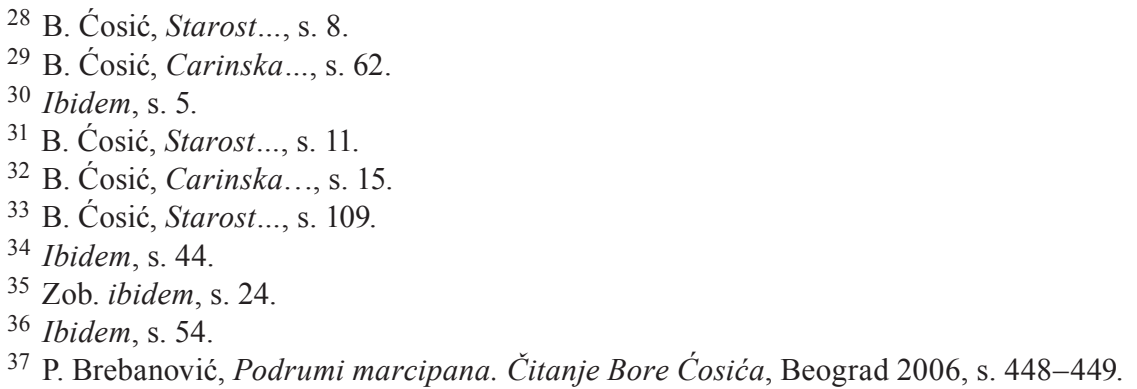


Iliji Kabakova. Koncentruje się także na współtowarzyszach emigracyjnego losu. Kolejne strony berlińskich zapisków zapełniają refleksje po lekturze tekstów innych dysydentów, wspomnienia i przemyślenia przyjaciół oraz znajomych ${ }^{38}$. Jako nowy mieszkaniec (novi stanar) często spaceruje po mieście, odkrywając dotąd nieznane jego przyjazne oblicze. To, co było obce i nieprzyjazne, przeistacza się w swojskie. ,[...] pratim proces, koji od tuđeg i nepoznatog pretvara se u sopstveno" 39 — podkreśla pisarz. Spacer ma tutaj wymiar terapeutyczny, pozwala oswoić się z nową sytuacją, uporządkować myśli, okiełznać emocje:

U mladosti mnogo sam hodao. Obilazio sam sve ulice, velike i male, pa čak i one koje su se, slepo, završavale u nečijem dvorištu. Hodao sam čitave noći, hodao sam po jutru i u prvi sumrak. [...] To je trajalo vrlo dugo. [...] Čovek u hodu, koji je uz to i očajan, neprestano misli da će se to očajanje zaustaviti u neki momenat, samo treba hodati i dalje, bez razmišljanja. [...] Hodanje je za mene sredstvo da pređem neku granicu u vlastitoj duši ${ }^{40}$.

Dzięki spacerom autor poznaje historię, która drzemie pod ulicami, w elewacjach budynków, w sztukaterii mieszkania. W przestrzeni miejskiej odnajduje także ślady własnej przeszłości, którą utracił. Przestronne apartamenty w starych kamienicach przypominają mu mieszkania z okresu Królestwa Jugosławii, a socjalistyczna architektura wschodniego Berlina przywołuje w pamięci zakątki Belgradu. Nawet w przypadkowo spotkanych ludziach widzi znajomych:

[...] ja se ovde osećam sasvim dobro i kao da svaku ulicu poznajem već od ranije. [...] juče sam u ulici Wieland video gospođu koja pere prozore onako kako je moja mama, u davna doba, puno puta činila. [...] u Berlinu pronalazim svoju davno nestalu mamu ${ }^{41}$.

Kontakt z przestrzenią miasta ożywia wspomnienia, wracają nazwy ulic, placów, budynków, osób. Tutaj pisarz odnajduje fragment samego siebie i straconej przeszłości. Dzięki temu również Berlin zaczyna postrzegać w jaśniejszych barwach. Różnicę między stolicą Niemiec a miejscem, z którego przybył, ukazuje za pośrednictwem motywu domu. Dawne mieszkanie Ćosicia było małe z ciasnymi i zagraconymi pokojami, o których mówi: „,male sobe naše civilizacije”2 ${ }^{\text {. Natomiast }}$ jeszcze nieumeblowane pomieszczenia w berlińskim domu są jasne i przestronne. Mieszkanie to autor nazywa „golema soba naše sadašnjice" ${ }^{43}$, podkreślając, że:

[...] vrlo mnogo obećava u nekom budućem vremenu. Jer soba koja je nameštena i prepuna stvari ne obećava svome stanaru ništa, osim moru i vrlo veliku teskobu. A ona koja je prazna izgleda kao svet, stvoren toga jutra, i kome predstoji možda veoma slavna budućnost ${ }^{44}$.

38 Predrag Brebanović zwraca uwagę na pewne podobieństwa między „,berlińskimi” tekstami Ćosicia a utworami innych twórców pochodzących z Jugosławii - Miloša Crnjanskiego (Iris Berlina), Dubravki Ugrešić (Muzeum bezwarunkowej kapitulacji) oraz Ireny Vrkljan (Berlinski rukopis). Zob. ibidem, s. 451, 455.
${ }^{39}$ B. Ćosić, Starost..., s. 15-16.
${ }^{40}$ B. Ćosić, Carinska..., s. 24.
${ }^{41}$ B. Ćosić, Novi stanar, Beograd 1998, s. 22.
${ }^{42}$ Zob. B. Ćosić, Carinska..., s. 80.
43 Zob. ibidem, s. 81 .
44 Ibidem, s. 93. 
Bijącą z przytoczonego fragmentu nadzieję, która przepełnia serce pisarza, odnieść należy nie tylko do jego egzystencji w nowym miejscu, ale i nowego etapu życia, jakim jest starość. Dzięki spotkaniu z przestrzenią Berlina autor odzyskuje pamięć, która - jak pisze Sabina Giergiel — „staje się rodzajem przekraczania śmierci”45. Ten przełomowy moment Ćosić nazywa „przejściem granicznym swojego życia"46. Wyraźnie zmienia się również jego nastawienie względem starości, którą zaczyna postrzegać z optymizmem, koncentrując się przede wszystkim na kolejnych wyzwaniach, które okres ten przed nim stawia. Autor zdał sobie sprawę, że życie toczy się dalej i otwiera się na nowe doświadczenia i nowych ludzi. Rozliczenie się z traumatycznym doświadczeniem utraty ojczyzny uchyliło przed pisarzem furtkę do pomyślnej starości, bo - powtórzmy raz jeszcze — „pozytywne starzenie się musi zawsze odzwierciedlać istotną reakcję na zmiany”47. Ewolucję postawy wobec życia oraz własnej starości w najpełniejszy sposób oddają słowa pisarza: „urodziłem się w Zagrzebiu, zmarłem w Belgradzie, mieszkam w Berlinie" 48 .

Odzyskanie pamięci — klucz do pozytywnej starości — w znaczący sposób wpłynęło również na kształt kolejnych utworów Bory Ćosicia. Teksty powstałe po roku 2000, a mam tu na myśli przede wszystkim takie tytuły, jak: Podróż na Alaskę, Konsul w Belgradzie oraz Mirni dani u Rovinju, bazują na wspomnieniach, są relacjami z mentalnych oraz realnych podróży autora. Każdy stanowi rodzaj putopisu. O ile w przypadku pierwszego z wymienionych utworów mamy do czynienia z podróżą w przestrzeni — do Chorwacji, Serbii i Bośni, to w przypadku drugiego jest to podróż w czasie: do okresu dzieciństwa i młodości, gdy autor mieszkał w Belgradzie. $Z$ kolei trzeci tekst to relacja z podróży po znajdującym się w Rovinju domu pisarza ${ }^{49}$. W każdym z utworów odnajdujemy również wiele odniesień do szeroko rozumianej teraźniejszości — w postaci relacji ze spotkań, ważnych wydarzeń, przebiegu rozmów ze znajomymi czy codziennych, prozaicznych czynności. Wysuwają się one na plan pierwszy, zwłaszcza w ostatnim utworze, w którym autor dokonuje podsumowania własnego życia. Ćosić, zapraszając czytelnika do domu, przestrzeni prywatnej, intymnej, otwiera się

45 S. Giergiel, Ocalić pamięcią. Praktyki pamięci we wspótczesnej prozie postjugosłowiańskiej, Opole 2012, s. 211.

46 „Granični prelaz svoga života”. B. Ćosić, Carinska ..., s. 40.

${ }^{47}$ G.E. Vaillant, Aging Well..., s. 161.

48 N. Ožegović, Bora Ćosić - beogradski disident u Berlinu, „Nacional” br. 573 (200611-07), http://www.nacional.hr/clanak/28900/bora-cosic-beogradski-disident-u-berlinu [dostęp: 7.05.2015].

49 Autor o tej niezwykłej formie pisze: „Ovaj putopis po jednoj kući pokazuje šta sve može sadržati ta mala država nečije sudbine; ovo je katalog mnogobrojnih predmeta, onde sakupljanih tokom više decenija, a potom popis velikog broja ljudi koji su kao gosti, prijatelji i poznanici boravili na ovom mestu. Mnogi od njih već su mrtvi, drugi su ostavili tu svoje umjetnine, otiske svojih stopala, svoj spomen. I svaka druga kuća pouzdano je muzej života svojih žitelja, samo se ovi najčešće ne sete da ih pobeleže. [...] Možda nijedan dom ne mora da nadživi svoje stanovnike, [...], ali zato nije loše da ostane zapis o tome kakav bio je". B. Ćosić, Mirni dani u Rovinju, Zagreb 2014, s. 5. 
przed nim i zwierza. Z zapisków tych wyłania się obraz twórcy, który, licząc ponad osiemdziesiąt wiosen, zdaje się niestrudzony długim życiem, dużo pracuje, wydaje nowe książki, nieustannie publikuje na łamach poczytnych europejskich czasopism, bierze udział w wielu wydarzeniach artystycznych, odczytach, wykładach czy spotkaniach z czytelnikami. Jest to obraz człowieka szczęśliwego, spełnionego, odczuwającego satysfakcję ze swojego życia i pracy, człowieka w pełni świadomego własnej wartości i pozycji, jaką zajmuje. Cieszy się ogromną sympatią, co potwierdzają opisy wizyt niezliczonych przyjaciół i znajomych. Jego dom jest miejscem spotkań wielu artystów, enklawą, gdzie każdy znajdzie kąt dla siebie.

Ćosić, mówiąc o swoim życiu osobistym, w zupełności godzi się z tym, co przyniósł mu los. Pogodzony jest również ze swoją starością. Ukazuje ją jako towarzyszkę, kompankę. Doświadcza jej obecności na co dzień i nie wzbrania się przed nią. Postrzega ją przede wszystkim jako cechę własnej fizyczności, a nie intelektu:

Ja sam već dovoljno star, da mi ne prija mnogo vrzmanja po kući, pa vrlo često osetim sitni ropski čin: treba da dohvatim ovu stoličicu kako bih je podmetnuo pod noge, a da to postignem, sevnuće me malo u leđima, jedino što će potom narodu moga tela biti, kao u carstvu slobode, mnogo bolje, nesravnjeno bolje! To je deo svakodnevne dijalektike, svako ugađanje sebi samom vuče taj rep za sobom, tihe muke. Osim toga, samo stari čovek u stanju je da odmeri svu nespretnost, nepodobnost ljudskog fizisa da dohvati ovo ili ono, nesposobnost da prekorači tamo gde treba, da obavi nešto, naoko sasvim jednostavno, starac je meritoran da prizna nepodesnost naše životinjske vrste za njen život na zemlji ${ }^{50}$.

Pisarz ze spokojem obserwuje, jak starość wpływa na jego egzystencję. Stara się dostrzegać w niej pozytywne strony oraz przekuć ją w doświadczenie wzbogacające i przynoszące satysfakcję. W ujęciu Ćosicia staje się ona nie tylko naturalnym etapem życia, ale wręcz darem, który należy w możliwie najpełniejszy sposób wykorzystać. W jednym z wywiadów pisarz stwierdza:

Znate što, za sada se ne mislim sumirati jer se ne osjećam toliko staro, iako imam puno godina. Moja oba djeda doživjeli su više od 90 godina pa prema tome imam vremena za sumiranje. Mislim da ne moram biti nezadovoljan, radim stvari koje ljude vesele, pa to onda veseli i mene ${ }^{51}$.

Autor jednocześnie podkreśla, że tajemnica jego długowieczności kryje się w pracy, aktywności intelektualnej, nieustannym wyznaczaniu sobie nowych celów i wyzwań:

Kada u starosi ljudi se katkad prepuste onom tihom neradu, u sedenju i možda gustom razmišljanju, pitam se da li tom svojom prividnom hiberniranošću skraćuju sopstveni vek, ili ga, naprotiv, produžuju? ${ }^{52}$

${ }^{50}$ Ibidem, s. 33.

${ }^{51}$ N. Ožegović, Bora Ćosić...

52 B. Ćosić, Mirni dani..., s. 70-71. 
Przytoczone pytanie potwierdza, że pisanie, aktywność literacka nie tylko jest dla twórcy sposobem na uniknięcie negatywnych konsekwencji starości, ale może wydłużyć życie i podnieść jego jakość, uczynić je lepszym i pełniejszym.

Kończąc swoje rozważania, raz jeszcze pragnę przywołać słowa Ćosicia, który o książce Mirni dani u Rovinju pisze: „Među više rukopisa koji pokušavaju opisati moj dugi vek, ova knjiga nekako je na sredini, kao jedno podne pisanja, podnevni izveštaj" ${ }^{53}$. Zważając na tempo pracy pisarza, należy się spodziewać, że nie będzie to jego ostatni utwór ${ }^{54}$. Pozostaje zatem czekać na „raport” popołudniowy i wieczorny.

\section{Bibliografia}

Bauman Z., Życie na przemiat, Kraków 2004.

Brebanović P., Podrumi marcipana. Čitanje Bore Ćosića, Beograd 2006.

Ćosić B., Carinska deklaracija, Split 2000.

Ćosić B., Mirni dani u Rovinju, Zagreb 2014.

Ćosić B., Novi stanar, Beograd 1998.

Ćosić B., Starost u Berlinu, Beograd 1998.

Giergiel S., Ocalić pamięcią. Praktyki pamięci we współczesnej prozie postjugosłowiańskiej, Opole 2012.

Gostomska A., Zagrzeb - Berlin - Amsterdam. O metaforze miasta w twórczości Dubravki Ugrešić, [w:] Miasto w kulturze chorwackiej, red. M. Falski, M. Kryska-Mosur, Warszawa 2008.

Gronostaj A., „Pozytywna starość” w opowiadaniu Ernesta Hemingwaya „Stary człowiek i morze", [w:] Wielkie tematy literatury amerykańskiej VI. Starość. Śmierć, red. T. Pyzik, A. Woźniakowska, Katowice 2014.

Hartwig J., *** (Stary człowiek upadł w błoto), [w:] eadem, Chwila postoju, Kraków 1980.

Hill R.D., Pozytywne starzenie się. Młodzi duchem w jesieni zycia, przeł. M. Lipa, Warszawa 2009. Minois G., Historia starości. Od antyku do renesansu, przeł. K. Marczewska, Warszawa 1995.

Nowak-Starz G. et.al., Społeczny obraz starości XXI wieku, [w:] Starość - obawy, nadzieje, oczekiwania. Wybrane zagadnienia z gerontologii, red. B. Zboiny, G. Nowak-Starz, Ostrowiec Świętokrzyski 2009.

Ožegović N., Bora Ćosić — beogradski disident u Berlinu, „Nacional” br. 573 (2006-11-07), http:// www.nacional.hr/clanak/28900/bora-cosic-beogradski-disident-u-berlinu.

Seligman M.E.P., Csikszentmihalyi M., Positive psychology: An Introduction, „American Psychologist” 2000, nr 55.

Tyszkowska-Kasprzak E., Stolica na emeryturze. Petersburg w prozie Olega Postnowa, [w:] Topografia tożsamości, t. 1, red. B. Zieliński, Poznań 2012.

Vaillant G.E., Aging Well. Surprising guideposts to a happier life, Boston 2002.

Vukčević L., Svijet kao osobni muzej u pisanju Bore Ćosića, „Književna republika” 2013, br. 1-3.

Wysocka E., Człowiek „stary” w społeczeństwie ponowoczesnym - stereotyp starości i procesu starzenia się w świadomości młodzieży, [w:] Starość raz jeszcze..., red. J. Olejniczak, S. Zając, Katowice 2007.

Zych A., Stereotypowe wyobrażenia oraz mity na temat starości i ludzi w podeszłym wieku, [w:] idem, Człowiek wobec starości. Szkice z gerontologii społecznej, Warszawa 1995.

53 Ibidem, s. 97.

${ }^{54}$ W 2015 r. w Chorwacji ukazał się zbiór poezji autorstwa Bory Ćosicia. Zob. B. Ćosić, Razvoj kraljičinog gardiste, Zagreb 2015. 


\section{The experience of old age in the autobiographical prose of Bora Ćosić}

\section{Summary}

In this article, I focused my attention on the vision of aging and attitude towards this phenomenon which are present in Ćosic's autobiographical prose. Based on texts, which were published after the year 1995, like Novi stanar (1998), Starost u Berlinu (1998), Carinska deklaracija (2000), Put na Aljasku (2006), Consul u Beogradu (2008) and the latest collection of writings entitled Mirni dani u Rovinju (2014), I made the reconstruction of the writer maturation process to a positive / successfull aging. This one of the most famous post-Yugoslav stateless left Rovinj in 1995, were he moved from Belgrade in 1991, and then moved to Berlin, where he has been living during this time. At the beginning the German capital appears to Cosić as an unfriendly place that enhances the writer's sense of alienation and old age. The writer defined his origin country as "the southern land", while Berlin is a city in the north, which has became in his view a synonymous of old age or even death. On the pages of his works the author showed how gradually became familiar with this alien space. He found traces of his past and his former life in Belgrade in the urban space of Berlin. The recovery of memory and recollection open a new phase in the work of Bora Ćosić. Based on his works published after 2000 we could get a a picture of the artist, who seems to be a tireless of his long life and has a lot of work to do, who publishes new books and who is involved in many artistic events, readings and meetings with readers although he is 80 . Ćosić is reconciled with old age and totally agrees with what fate brought to him. The evolution of attitudes towards life and old age are shown in the most complete way by his words that he often repeats: „I was born in Zagreb, I died in Belgrade, I live in Berlin".

Keywords: Bora Ćosić, autobiographical prose, positive/successful aging, memory

\section{Doživljaj starosti u autobiografskoj prozi Bore Ćosića}

\section{Rezime}

U članku sam obratila pažnju na piščev doživljaj starosti. Zahvaljujući analizi autobiografskih knjiga, pre svega tekstova koje je autor objavio posle 1995. godine, kao što su: Novi stanar (1998), Starost u Berlinu (1998), Carinska deklaracija (2000), Put na Aljasku (2006), Consul u Beogradu (2008) i najnovija zbirka beležaka pod naslovom Mirni dani u Rovinju (2014), trudim se da ukažem Ćosićev put od negativne do pozitivne/uspešne starosti. Taj, jedan od najpoznatijih postjugoslavenskih apatrida, 1995. godine napustio je Rovinj, u koji se preselio iz Beograda 1991. godine i otišao je u Berlin gde živi do danas. Čitajući tekstove, koje je autor napisao na početku svog boravka u nemačkoj prestonici, može se zapaziti da se tamo osećao pre svega kao drugi, kao stranac. Osećaj tuđinstva je izazivao i pojačavao osećaj starosti. Pisac je često ponavljao da je njegova otadžbina ostala na jugu, a on je došao na sever, koji je podrazumevao kao sinonim starosti, čak i smrti. U svojim tekstovima autor je zabeležio kako je upoznavao grad i otkrivao mnogo kutaka koji su ga podsećali na život u Beogradu. Na berlinskim ulicama i u starim zgradama pronašao je tragove svoje prošlosti. Zahvaljujući tome počeo je da se oseća u Berlinu kao u nekoj vlastitoj prostoriji. Stekao je pamćenje i na taj način prekoračio je smrt. Povratak pamćenja, memorije, otvara novu fazu u Ćosićevom stvaralaštvu. U knjigama, koje je autor objavio posle 2000. godine, nalazimo sliku starog čoveka, koji uprkos svojoj starosti nije umoran, mnogo radi i uživa u tome, 
stalno izdaje nove knjige, učestvuje u mnogim umetničkim događajima, izlaganjima i sastancima. Prihvata svoju starost i slaže se sa time što mu je život doneo. Promenu stava prema životu i starosti na najbolji način pokazuje rečenica koju Ćosić često ponavlja: „Moja kratka biografija u tri reda glasi: rođen sam u Zagrebu, umro u Beogradu, živim u Berlinu”.

Ključne reči: Bora Ćosić, autobiografska proza, pozitivna/uspešna starost, memorija 